\title{
Analisis Gerombol Simultan dan Jejaring Farmakologi antara Senyawa dengan Protein Target pada Penentuan Senyawa Aktif Jamu Anti Diabetes
} Tipe 2

\section{Penulis}

Afiliasi

\author{
Nurul Qomariasih ${ }^{1^{*}}$, Budi Susetyo ${ }^{2}$, Farit Mochamad Afendi ${ }^{3}$ \\ ${ }^{1}$ Program Studi Statistika, Sekolah Pascasarjana Institut Pertania Bogor, Indonesia. \\ ${ }^{2}$ Departemen Statistika, Institut Pertanian Bogor, Indonesia. \\ ${ }^{3}$ Departemen Statistika, Institut Pertanian Bogor, Indonesia.
}

\section{Abstrak}

Selama ini pembuatan obat untuk menyembuhkan suatu penyakit masih menargetkan hanya satu protein khusus yang menjadi penyebab penyakit tersebut, yang tentu hanya menggunakan satu senyawa aktif. Padahal selain menimbulkan efek samping, penanganan suatu penyakit perlu menyasar banyak protein sekaligus. Sehingga, barubaru ini terjadi perubahan paradigma dari "one drug, one target" menjadi "multicomponents, network target". Paradigma baru ini telah melahirkan beberapa penelitian untuk menghasilkan formulasi jamu, hal ini dikarenakan konsep formulasi jamu memerlukan beberapa senyawa aktif yang terlibat. Formula jamu yang diteliti sebagai upaya menyembuhkan penyakit Diabetes Melitus (DM) tipe 2 terdiri dari 4 tanaman yaitu Pare (Momordica charantia), Sembung (Blumea balsamifera), bratawali (Tinospora crispa), dan jahe (Zingiber officinale) berdasarkan hasil penelitian Nurishmaya tahun 2014 serta berdasarkan ramuan jamu yang sedang dikembangkan di Pusat Studi Biofarmaka, Bogor. Evaluasi senyawa yang berkaitan dengan DM tipe 2 dilakukan dengan terlebih dahulu menambahkan 19 obat sintetis yang ditujukan untuk DM tipe 2 dari basis data Drug Bank. Sehingga terdapat total sebanyak 74 senyawa aktif yang terdiri dari 55 senyawa alami dari tanaman dan 19 senyawa sintetis obat. Sebanyak 100 protein yang berkaitan erat dengan masing-masing senyawa diperoleh melalui hasil skor konkordan DrugCHIPER. Skor konkordan tersebut kemudian digunakan dalam analisis gerombol simultan antara senyawa dan protein target. Plot komponen utama dan submatrix penggerombolan simultan menunjukkan 2 dari 3 senyawa dari bratawali sangat dekat dengan kelompok sintetis. Selain itu, ada 11 dari 44 senyawa dari Jahe terkumpul bersama dengan senyawa sintetis tetapi dalam jarak yang jauh. Sedangkan berdasarkan jejaring kemiripan, lebih spesifik lagi terdapat 17 dari 19 senyawa obat sintetis yang memiliki kemiripan berdasarkan protein target dengan 2 senyawa tanaman Bratawali dan 5 senyawa tanaman Jahe.

\section{Pendahuluan}

Seiring perkembangan jaman, kecenderungan orang memilih bahan alami untuk konsumsi sehari-hari maupun pengobatan semakin berkembang. Pemilihan bahan 
alami pada bidang pengobatan terlihat dari banyaknya orang mengonsumsi obat herbal dan jamu sebagai pengobatan maupun pencegahan terhadap suatu penyakit. Fenomena tersebut sesuai dengan perubahan paradigma pengobatan yang ramai menjadi topik penelitian saat ini, yakni dari "one drug, one-target" menjadi "multi-components, network target". "one drug, one-target" mengacu kepada obat kimia sintetis yang berisi satu senyawa aktif untuk mengobati satu keluhan penyakit tertentu. Namun terkadang obat seperti ini menimbulkan efek samping. Sedangkan "multi-components, network target" diterapkan salah satunya pada jamu yang memiliki konsep keterlibatan beberapa senyawa aktif untuk menargetkan beberapa protein penyebab penyakit.

Ketika membuat obat sintetis dengan pendekatan farmasi, langkah pertama yang ditempuh adalah mengidentifikasi fungsi dari target yang mungkin dan peranannya dalam penyakit. Langkah kedua adalah validasi target, dalam langkah ini diperlukan demonstrasi bahwa molekul target secara langsung terlibat dalam proses penyakit. Langkah selanjutnya adalah identifikasi senyawa aktif yang didefinisikan sebagai molekul yang menunjukkan aktifitas biologis signifikan dalam uji skrining, yakni materi baru yang menghubungkan struktur kimia untuk modulasi target. Hingga langkah terakhir, yaitu langkah ke-11 yang melibatkan pengujian klinikal atas konsep obat yang telah dibuat. Berdasarkan serangkaian langkah tersebut, maka akan didapatkan molekul target (protein) yang berperan terhadap penyebab suatu penyakit tertentu dan senyawa aktif obat sintetis yang berfungsi untuk menargetkan molekul tersebut. Fungsi dari senyawa aktif adalah mengunci protein target dalam rangka penyembuhan suatu penyakit, atau keduanya diistilahkan sebagai "lock and key".

Selain bidang farmasi, terdapat beberapa penelitian dalam rangka mengembangkan pembuatan Jamu melalui serangkaian proses menggunakan pendekatan lain seperti statistika dan komputasi. Afendi et al. (2010) telah melakukan penelitian mengenai pemodelan bahan jamu untuk memprediksi khasiat menggunakan analisis statistika Partial Least Square Discriminant Analysis (PLS-DA). Selain itu, Nurishmaya (2014) juga melakukan penelitian mengenai tanaman obat berkhasiat yang dipilih melalui serangkaian uji statistika dilanjutkan dengan uji laboratorium pada ikan zebra (Danio rerio) untuk pengujian persentase kadar gula darah bagi penderita diabetes. Data yang digunakan pada penelitian Nurishmaya (2014) merupakan hasil penelitian Afendi et al. (2010) yaitu 2748 jamu, 231 tanaman, dan 9 khasiat. Berdasarkan hasil penelitian tersebut terdapat empat tanaman obat berkhasiat yang dapat dibuat sebagai formulasi Jamu antidiabetes yaitu Pare (Momordica charantia), Sembung (Blumea balsamifera), Bratawali (Tinospora crispa), dan Jahe (Zingiber officinale). Keempat tanaman tersebut juga berdasarkan ramuan jamu yang sedang dikembangkan di Pusat Studi Biofarmaka, Bogor.

Berdasarkan langkah-langkah pembuatan obat secara farmasi di atas, terdapat suatu proses yaitu penemuan senyawa aktif yang dapat mengikat protein penyebab penyakit - "lock and key". Sedangkan berdasarkan penelitian Nurishmaya (2014) terdapat empat tanaman yang berguna untuk dijadikan formulasi jamu antidiabetes. Maka dalam penelitian ini akan dilakukan pencarian senyawa aktif dari empat tanaman obat yang memiliki aktifitas biologi terhadap protein penyebab diabetes menggunakan pendekatan statistika dan komputasi. Metode statistika yang sesuai digunakan adalah penggerombolan berhirarki dua dimensi, yaitu serupa dengan penelitian yang dilakukan oleh Parsons et al. (2004) mengenai integrasi data kimia-genetik dan interaksi genetik untuk mengungkapkan informasi tentang jalur dan sasaran senyawa penghambat. Berdasarkan tujuan yang akan dicapai maka penelitian ini menggunakan data senyawa-protein dan interaksi protein. Data tersebut diperoleh melalui konsep jejaring farmakologi yaitu drugCIPHER (Zhao \& Li 2010). Sebelum menggunakan konsep drugCIPHER, terdapat beberapa data yang harus dicari seperti daftar obat kimia antidiabetes beserta senyawa, identitas Pubchem CID dan protein targetnya, selain itu adalah daftar senyawa dari keempat tanaman obat beserta daftar protein targetnya, daftar fingerprint, serta daftar interaksi biner protein target. Senyawa obat kimia antidiabetes perlu ditambahkan pada penelitian karena akan dicari kemiripannya berdasarkan protein target dengan senyawa tanaman obat. Untuk memperjelas hasil penggerombolan berhirarki dua dimensi khususnya hubungan antara senyawa obat dengan senyawa yang berasal dari tanaman, hasil gerombol senyawa divisualisasi melalui jejaring kemiripan menggunakan perangkat lunak Cytoscape (Li Huiying et al. 2014).

Berdasarkan pemaparan di atas maka penelitian ini bertujuan untuk melakukan pendekatan 
statistika dan komputasi jejaring farmakologi dalam penentuan senyawa aktif tanaman obat antidiabetes berdasarkan protein target.

\section{Metode Penelitian}

Data

Data tanaman yang digunakan merupakan data tanaman berkhasiat anti diabetes tipe 2 berdasarkan penelitian Nurishmaya (2014) dan merupakan tanaman obat yang sedang dikembangkan di Pusat Studi Biofarmaka, terdiri dari Pare (Momordica charantia), Sembung (Blumea balsamifera), Bratawali (Tinospora crispa), dan Jahe (Zingiber officinale). Daftar lebih rinci mengenai bahan aktif dari tanaman-tanaman tersebut dicari lebih lanjut melalui berbagai publikasi ilmiah yang dilakukan selama bulan Januari hingga Mei 2015 seperti tertera pada Tabel 1.

\section{Metode Analisis}

\section{Pendugaan protein target}

Tahap ini menggunakan metode drugCIPHER dengan langkah-langkah sebagai berikut (Zhao \& Li 2010):

1. Mendapatkan matriks drugCIPHER-CS

a. Menggabungkan data 55 senyawa tanaman dan 19 senyawa obat menjadi total keseluruhan 74 senyawa dilengkapi dengan Simplified Molecular-Input LineEntry System (Smiles).

b. Membuat set biner sepanjang 4860 bit untuk masing-masing senyawa berdasarkan fingerprint $\mathrm{KR}$.

Tabel 1. Daftar pangkalan data publikasi ilmiah

\begin{tabular}{|c|c|c|c|}
\hline Data & $\begin{array}{l}\text { Pangkalan } \\
\text { Data }\end{array}$ & $\begin{array}{l}\text { Informasi yang diperoleh dari } \\
\text { pangkalan data }\end{array}$ & Hasil penelusuran data \\
\hline \multirow[t]{2}{*}{ Senyawa } & $\begin{array}{l}\text { Take Out } \\
\text { "Jamu" of } \\
\text { Knapsack }\end{array}$ & $\begin{array}{l}\text { Daftar senyawa dari tanaman Jahe, Pare, } \\
\text { Sembung, dan Bratawali. (Afendi et al. } \\
\text { 2012, Running WE 1993) }\end{array}$ & $\begin{array}{l}291 \text { senyawa jahe, } 18 \text { senyawa } \\
\text { bratawali, } 41 \text { senyawa sembung, } \\
\text { dan } 245 \text { senyawa pare. Total } \\
\text { jumlah senyawa sebanyak } 595\end{array}$ \\
\hline & $\begin{array}{l}\text { DrugBank } \\
\text { Database }\end{array}$ & $\begin{array}{l}\text { Senyawa obat kimia sintetis antidiabetes } \\
\text { (Wishart et al. 2008) }\end{array}$ & $\begin{array}{l}19 \text { senyawa aktif obat sintetis } \\
\text { anti-diabetes. }\end{array}$ \\
\hline Bahan aktif & Pubchem & $\begin{array}{l}\text { Daftar senyawa (tanaman \& sintetis) } \\
\text { yang memliki aktifitas biologis serta } \\
\text { informasi lebih rinci seperti Simplified } \\
\text { molecular input line entry system } \\
\text { (Smiles) dan PubChem ID (CID).(Wang et } \\
\text { al. 2009) }\end{array}$ & $\begin{array}{l}\text { Dari jumlah total } 595 \text { senyawa } \\
\text { tanaman, terdapat } 288 \text { senyawa } \\
\text { unik dengan informasi yang } \\
\text { lengkap. Sedangkan semua } \\
\text { senyawa obat sintetis memiliki } \\
\text { informasi yang lengkap. }\end{array}$ \\
\hline $\begin{array}{l}\text { Finger- } \\
\text { print } \\
\text { Klekota } \\
\text { Roth (KR) }\end{array}$ & ChemDes & $\begin{array}{l}\text { Daftar kriteria fingerprint (Klekota \& } \\
\text { Roth 2008) }\end{array}$ & $\begin{array}{l}\text { Terdapat sebanyak } 4860 \\
\text { substruktur molekul senyawa. }\end{array}$ \\
\hline $\begin{array}{l}\text { Interaksi } \\
\text { antar } \\
\text { protein } \\
\text { target }\end{array}$ & $\begin{array}{l}\text { Human } \\
\text { Protein } \\
\text { Reference } \\
\text { Database } \\
\text { (HPRD) }\end{array}$ & $\begin{array}{l}\text { Interaksi biner antar protein target } \\
\text { dalam tubuh. (Goel et al. 2012) }\end{array}$ & $\begin{array}{l}39.240 \text { interaksi biner antar } \\
9.673 \text { protein unik. }\end{array}$ \\
\hline $\begin{array}{l}\text { Konversi gi } \\
\text { number }\end{array}$ & $\begin{array}{l}\text { biological } \\
\text { DataBase } \\
\text { network } \\
\text { (bioDBnet) }\end{array}$ & $\begin{array}{l}\text { Identitas protein dalam bentuk selain gi } \\
\text { number.(Mudunuri et al.2009) }\end{array}$ & $\begin{array}{l}505 \text { HPRD ID untuk setiap } \\
\text { protein target. }\end{array}$ \\
\hline
\end{tabular}


c. Menghitung nilai kemiripan struktur molekul antar senyawa menggunakan koefisien Tanimoto (Sharma \& Pranit 2011):

$$
B T\left(Z_{i}, Z_{j}\right)=T\left(Z b_{i}, Z b_{j}\right)=\frac{Z b_{i} \times Z b_{j}}{\left\|Z b_{i}\right\|^{2}+\left\|Z b_{j}\right\|^{2}-Z b_{i} \times Z b_{j}}
$$

sehingga akan dihasilkan matriks kemiripan senyawa $(0<T<1)$ berskala interval berukuran $74 \times 74$.

\section{Menghitung drugCIPHER-GR $\left(\varphi_{\text {pd }}\right)$}

Metode drugCIPHER merupakan langkah dalam mengubah jejaring menjadi nilai numerik untuk penentuan senyawa aktif antidiabetes melalui metode analisis gerombol simultan. Metode ini akan menghasilkan protein target yang paling berperan dalam aktifitas senyawa aktif, baik tanaman maupun sintetis.

a. Menghitung jarak terdekat antara protein yang menjadi target (479 protein unik dari senyawa tanaman dan 43 protein dari obat) dengan seluruh protein dalam tubuh ( 9673 protein) yang terdokumentasi pada database HPRD menggunakan teori graf. Maka akan dihasilkan matriks jarak terpendek berskala rasio berukuran $505 \times 9673$.

b. Menghitung drugCIPHER-GR yaitu:

$$
\varphi_{p d}=\sum_{p_{k} \in T(d)} e^{-L_{p p k}^{2}}
$$

$L_{p p k}$ merupakan jarak terpendek yang dihasilkan dari poin (a). $e^{-L_{p p k}^{\pi}}$ digunakan untuk mengkonversi jarak protein-protein menjadi kedekatan protein-protein Dari perhitungan tersebut maka akan dihasilkan matriks kedekatan senyawa dengan protein berskala rasio berukuran $74 \times 9673$.

3. Menghitung nilai konkordan antara drugCIPHER-CS dengan drugCIPHER-GR:

$$
\rho_{p d}^{C}=\frac{\operatorname{cov}\left(C S_{d,} \varphi_{p d}\right)}{\sigma\left(C S_{d}\right) \sigma\left(\varphi_{p d}\right)}
$$

Nilai yang dihasilkan dari perhitungan di atas adalah sebuah matriks berukuran 74 senyawa $\times 9673$ protein. Lalu untuk masing-masing senyawa dipilih 100 protein target dengan nilai konkordan tertinggi. Sehingga akan dihasilkan matriks berukuran 74 senyawa $\times 1250$ protein target unik.

\section{Penggerombolan berhirarki 2 Dimensi (Govaert 1995).}

Perbedaan antara analisis gerombol klasik dengan analisis gerombol simultan adalah bahwa pada analisis gerombol klasik setiap objek pada gerombol objek didefinisikan menggunakan semua peubah dan setiap peubah pada gerombol peubah mencirikan semua objek. Sedangkan pada analisis gerombol simultan, setiap objek di dalam bicluster dipilih hanya menggunakan subset peubah dan setiap peubah di dalam bicluster dipilih hanya menggunakan subset dari objek. Beberapa metode dasar yang akan diterapkan pada penelitian ini terdiri dari metode penggerombolan agglomerative (metode penggabungan) yaitu linkage methods seperti single linkage (jarak minimum atau tetangga terdekat), complete linkage (jarak terjauh atau tetangga terjauh), dan average linkage (jarak ratarata). Selain itu juga menggunakan metode Ward yang meminimumkan "loss of information" dari gabungan dua kelompok data, yaitu didefinisikan sebagai peningkatan kriteria jumlah kuadrat galat (ESS). Metode penggerombolan lain seperti median dan centroid tidak dipakai karena dikhawatirkan akan terjadi "inversion" yang membuat kesulitan dalam menginterpretasi gerombol yang terbentuk.

Sebanyak 100 protein target dari 74 senyawa yang telah didapat dari tahap sebelumnya, dipilih nilai konkordan dari protein uniknya saja, yaitu sebanyak 1.250 protein. Lalu, nilai konkordan ukuran $74 \times 1250$ dibuat penggerombolan simultan 2 dimensinya menggunakan jarak Euclid dan menggunakan metode Single Linkage, Complete Linkage, Average Linkage, serta Ward.D dan Ward.D2 (Johnson \& Wichern 2002). Sedangkan algoritma yang dipakai adalah Coupled TwoWay Clustering Analysis (Getz et al. 2000). Hasil penggerombolan dievaluasi menggunakan Pseudo-F atau Variance Ratio Criterion (VRC):

$$
V R C=\frac{B G S S /(k-1)}{W G S S /(n-k)}
$$

Metode dan jumlah gerombol dengan nilai pseudo-F tertinggi akan dipilih (Calinski \& Harabasz 1974). Plot skor komponen utama dan similarity network terhadap senyawa juga ditampilkan untuk mendukung hasil gerombol simultan. 
Penentuan senyawa aktif dan tanaman antidiabetes dari hasil penggerombolan simultan 2 dimensi, plot PCA dan jejaring kemiripan.

Berdasarkan hasil penggerombolan simultan 2 dimensi, dapat dilihat senyawa-senyawa tanaman yang berperan sebagai antidiabetes serta tanaman asalnya. Pada saat yang sama, dapat dilihat pula protein apa saja yang ditargetkan oleh senyawa tersebut. Sedangkan plot PCA melihat kecenderungan pengelompokkan senyawa dan jejaring kemiripan memberikan gambaran kedekatan kemiripan antara senyawa sintetis dengan senyawa tanaman berdasarkan nilai similarity coefficient. Penggerombolan senyawa terhadap protein menghasilkan nilai kemiripan antara senyawa sintetis dengan senyawa tanaman. Nilai kemiripan tersebut bervariasi namun hanya nilai di atas 0.5 yang ditampilkan pada jejaring kemiripan (similarity network).

\section{Hasil dan Pembahasan} Jejaring Farmakologi

Jamu antidiabetes tipe 2 yang dicoba untuk dianalisis terdiri dari empat tanaman yaitu Jahe, Bratawali, Sembung, dan Pare. Total terdapat 288 senyawa aktif unik yang berasal dari Bratawali, Sembung, Pare dan Jahe masing-masing sebanyak 15 senyawa, 12 senyawa, 88 senyawa dan 173 senyawa. Setiap senyawa aktif terlibat dalam aktifitas beberapa protein, sedangkan setiap protein dapat ditargetkan oleh lebih dari satu senyawa. Sehingga hal tersebut membentuk sebuah jejaring farmakologi (Gambar 1).

\section{DrugCIPHER}

Jumlah senyawa tanaman yang diteliti dan memiliki identitas lengkap seperti struktur kimia dua dimensi (Inchi Key) dan memiliki protein target yaitu sebanyak 55 dari total 595 senyawa tanaman. Namun total senyawa yang akan dianalisis adalah sebanyak 74 , karena sebanyak 19 senyawa sisanya merupakan senyawa dari obat sintetis antidiabetes yang telah divalidasi oleh badan obat dan makanan Amerika Serikat. Pengukuran kemiripan senyawa berdasarkan struktur kimia ini penting dilakukan karena menurut Johnson \& Maggiora (1990), senyawa yang memiliki struktur kimia yang mirip akan memiliki sifat biologis yang mirip pula. Sehingga senyawa yang memiliki kemiripan akan cenderung mengikat protein yang sama. Pengukuran kemiripan dilakukan dengan menghitung koefisien Tanimoto, jangkauan nilainya antara 0 hingga 1 . Senyawa dengan kemiripan rendah ditunjukkan dengan warna biru pekat, sedangkan kemiripan tinggi ditunjukkan oleh warna yang lebih terang (Gambar 2). Dapat dilihat bahwa senyawa ke-4 memiliki kemiripan yang cukup tinggi dengan senyawa 5 hingga senyawa 9 dan memiliki nilai kemiripan mendekati 1.

Langkah selanjutnya yaitu pada ruang genomik (drugCIPHER-GR) menghitung jarak antar protein dalam tubuh menggunakan analisis graf dengan metode Dijkstra. Semakin dekat jarak antar protein, maka akan semakin cepat suatu senyawa melewati jalur tersebut

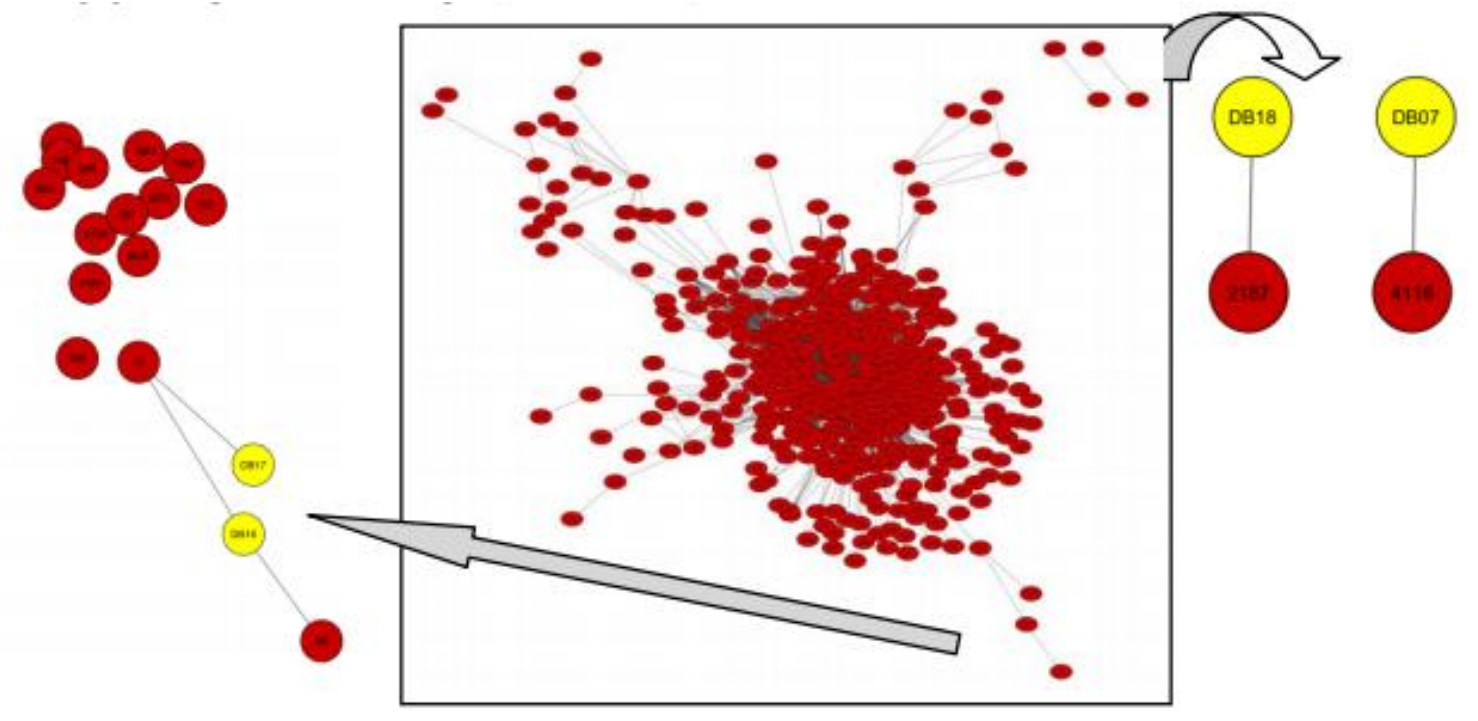

Gambar 1. Jejaring antara senyawa (kuning) dengan protein target (merah). 


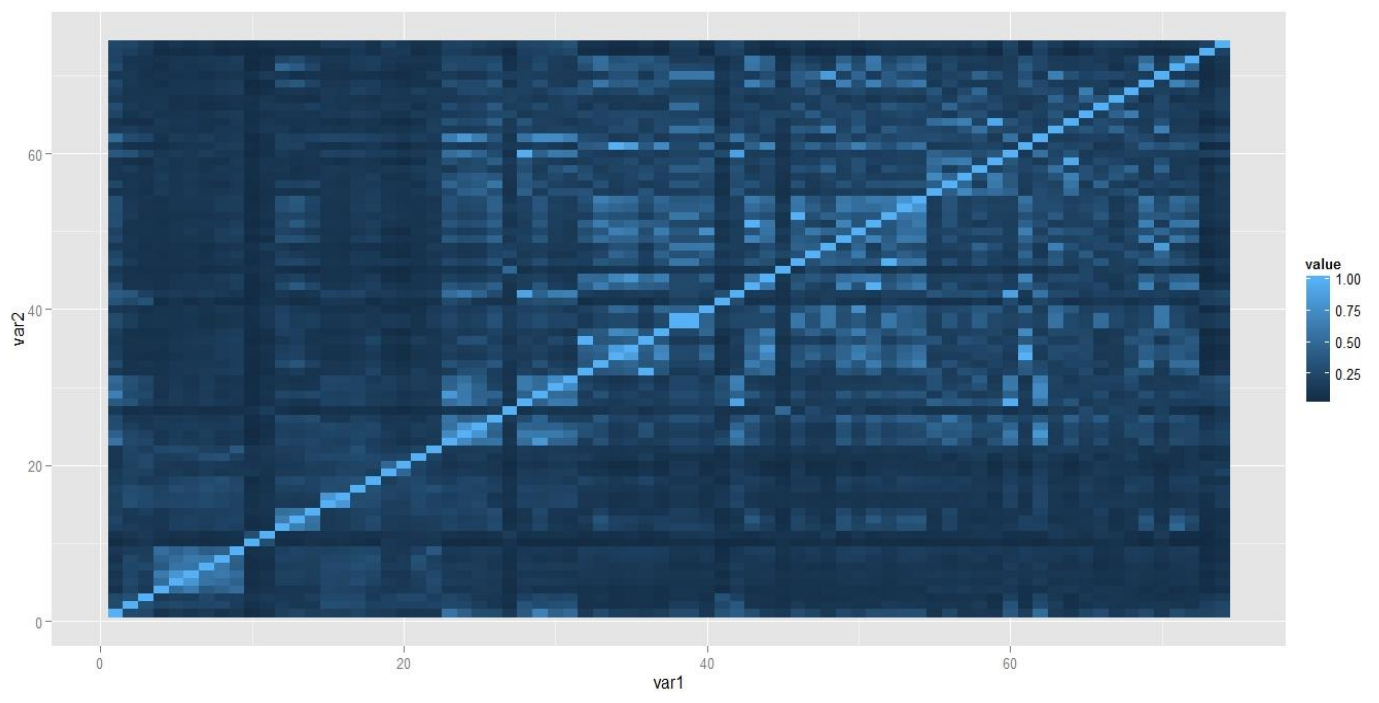

Gambar 2. Kemiripan antar senyawa berdasarkan struktur kimia yang dihitung melalui koefisien kemiripan Tanimoto.

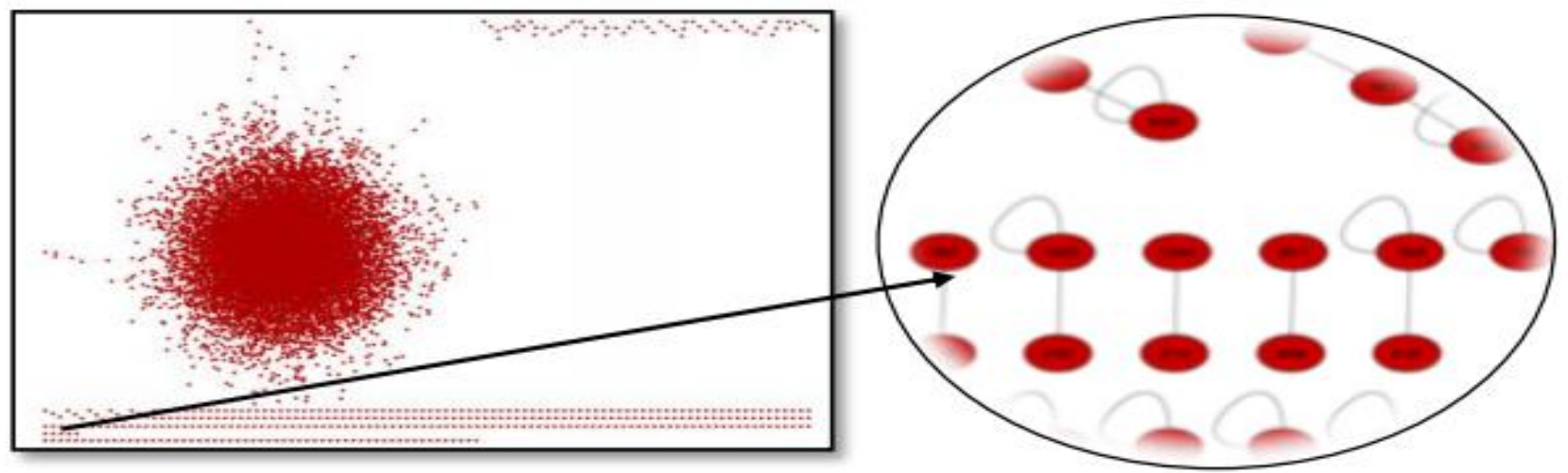

a. Jejaring semua protein

b. Interaksi antar protein

Gambar 3. Jejaring interaksi antar protein target

untuk menargetkan protein tertentu. Terdapat sebanyak 39240 interaksi antar 9673 protein unik (Gambar 3).

Jejaring protein dalam tubuh manusia ditunjukkan oleh Gambar 3a. Sebagian protein membentuk jejaring besar seperti bola dan sisanya berupa jejaring memisah yang terlihat di atas dan di bawah membentuk pola seperti garis. Tidak semua protein saling berinteraksi, ada yang berinteraksi dengan hanya 1 protein dan ada yang berinteraksi dengan dirinya sendiri (Gambar 3b). Jarak terpendek yang dicari adalah antara protein target ketujuh puluh empat senyawa sebanyak 505 protein dengan seluruh protein di dalam tubuh sebanyak 9673. Nilai jarak terkecil adalah 0 yang berarti bahwa kedua protein tidak saling berinteraksi sedangkan nilai 5 adalah seberapa banyak jalur protein lain yang dibutuhkan untuk menuju suatu protein yang ditargetkan.

Langkah terakhir drugCIPHER yaitu menghitung nilai korelasi (skor konkordan) antara ruang farmakologi dengan ruang genomik sehingga dihasilkan suatu nilai dengan rentang -1 hingga 1 yang menunjukkan semakin positif nilai korelasi maka suatu senyawa akan cenderung menargetkan protein tertentu. Lalu diambil sebanyak 100 protein dengan nilai korelasi tertinggi pada masing-masing senyawa untuk dianalisis lebih lanjut. Gambar 4a merupakan nilai konkordan 74 senyawa dengan 9673 protein dan Gambar 4b adalah nilai konkordan antara 74 senyawa dengan 100 protein. 


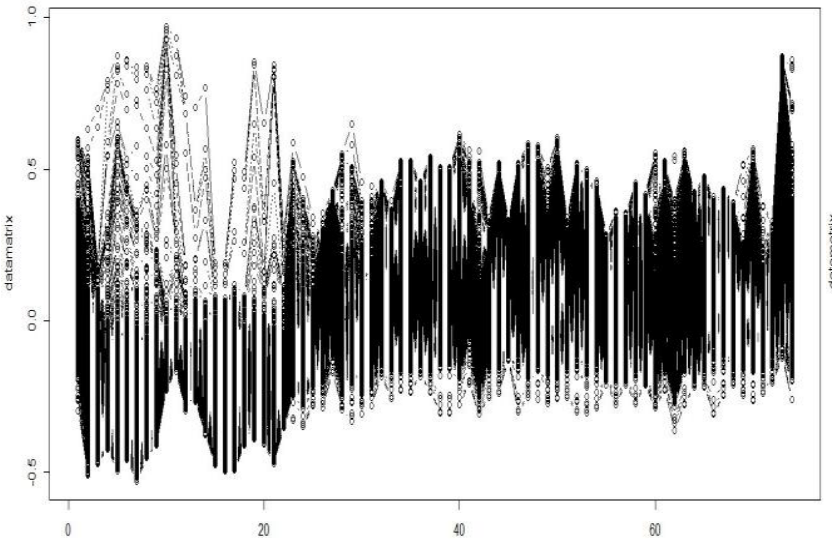

(a)

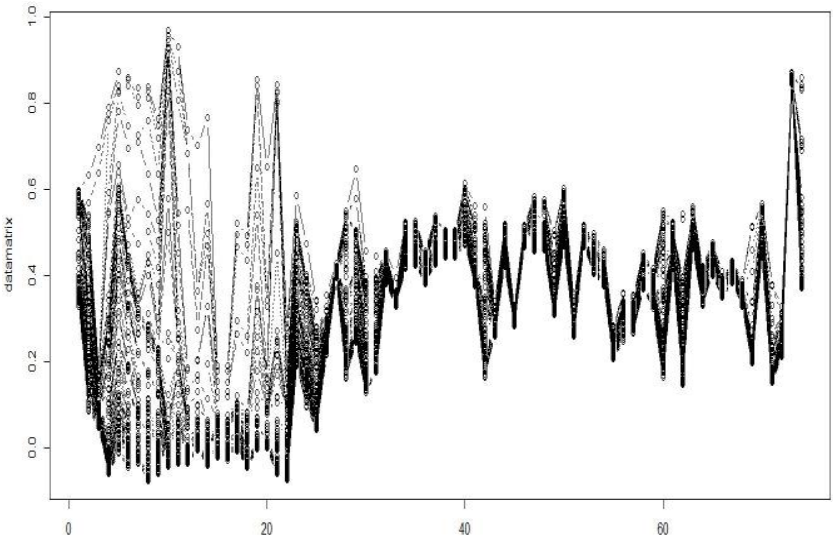

(b)

Gambar 4. Skor konkordan senyawa dengan protein target

Tabel 2. Nilai pseudo-F dari berbagai metode dan jumlah cluster

\begin{tabular}{cccccc}
\hline \multirow{2}{*}{$\begin{array}{c}\text { Jumlah } \\
\text { cluster }\end{array}$} & Complete & Single & Ward.D & Ward.D2 & Average \\
\cline { 2 - 5 } & 90.79095 & 1.181395 & 138.2402 & 134.9144 & 3.338005 \\
3 & 52.9918 & 2.510935 & 130.0341 & 130.0341 & 24.75602 \\
4 & 75.191 & 73.91926 & 104.3078 & 115.5557 & 74.485 \\
5 & 57.99236 & 64.53953 & 105.4843 & 109.783 & 84.3631 \\
6 & 56.31963 & 55.49613 & 94.8636 & 99.67659 & 68.54364 \\
7 & 50.16942 & 46.6784 & 82.59281 & 99.03075 & 75.16664 \\
8 & 50.36771 & 62.75198 & 88.89649 & 96.80158 & 80.89269 \\
9 & 48.69329 & 56.14139 & 91.29959 & 98.25854 & 89.44035 \\
\hline
\end{tabular}

\section{Analisis komponen utama}

Berdasarkan grafik scree plot (Gambar 5a), komponen yang harus diambil sebanyak 5 atau 6 dimana plot terlihat mulai stabil dan persentase keragaman yang dapat dijelaskan cukup besar yaitu 91.51\% hingga 93.44\%. Namun, karena keterbatasan dimensi, plot dibuat hanya untuk dua komponen (Gambar 5b) dengan persentase kumulatif keragaman sebesar $76.79 \%$ dan tiga komponen (Gambar 5c) dengan keragaman yang mampu dijelaskan sebesar 83.97\%. Baik plot 2 maupun 3 dimensi mengarah pada kesimpulan yang tidak berbeda jauh. Keduanya menunjukkan bahwa senyawa obat sintetis terlihat berkerumun; ungu pada plot 2 dimensi dan biru tua pada plot 3 dimensi. Sementara senyawa terdekat dari obat sintetik yaitu 2 senyawa dari tanaman brotawali; merah pada plot 2 dimensi dan kuning pada plot 3 dimensi. Pada plot 2 dimensi, beberapa senyawa dari Jahe (warna hijau) terlihat berdekatan dengan senyawa obat sintetis, tetapi pada plot 3 dimensi senyawa jahe (warna biru muda) terlihat cukup jauh.

\section{Penggerombolan berhirarki 2 dimensi}

Berbagai metode menghasilkan penggerombolan senyawa dan protein yang berbeda (Gambar 6). Dendogram pada sisi vertikal di masingmasing hasil penggerombolan menunjukkan hasil penggerombolan protein, sedangkan dendogram pada sisi horizontal merupakan hasil penggerombolan bagi senyawa. Setiap metode menghasilkan penggerombolan yang berbeda, sehingga dilakukan evaluasi terhadap metode dan jumlah gerombol yang terbaik menggunakan nilai pseudo- $F$ seperti ditampilkan pada Tabel 2. Nilai tersebut merupakan nilai untuk hasil penggerombolan senyawa. Nilai pseudo-F terbesar adalah untuk metode Ward.D sebesar 138.2402 dengan jumlah gerombol sebanyak 2 . Gambar 7a menampilkan bahwa gerombol senyawa 


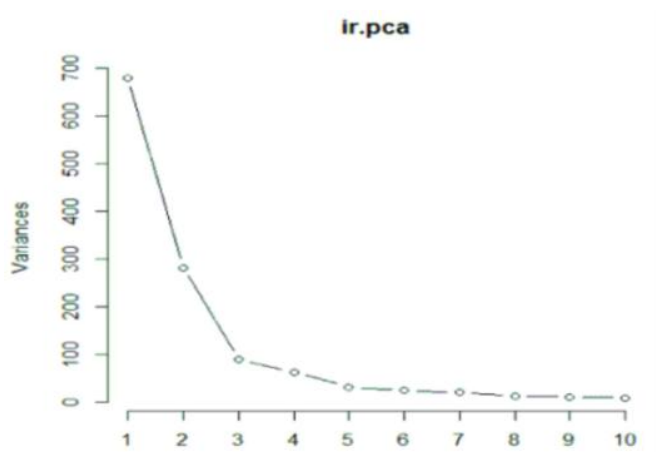

a. scree plot

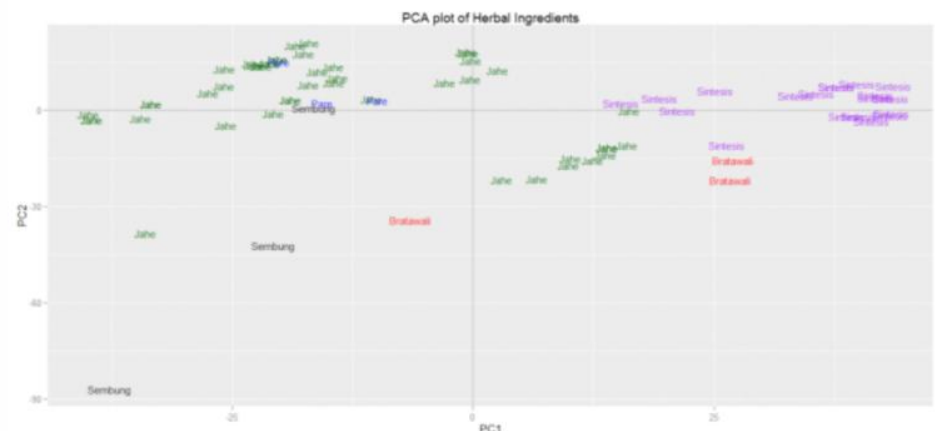

b. plot 2 komponen utama

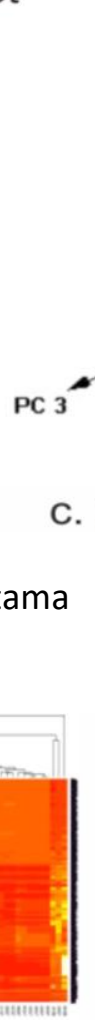

a. Single linkage

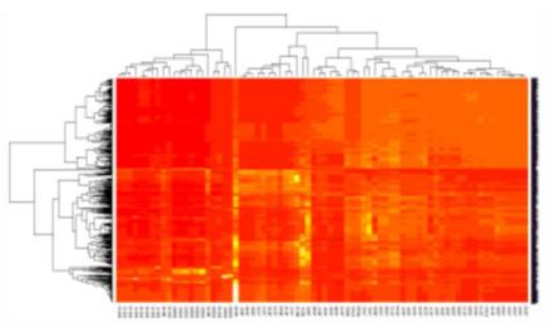

b. Complete linkage

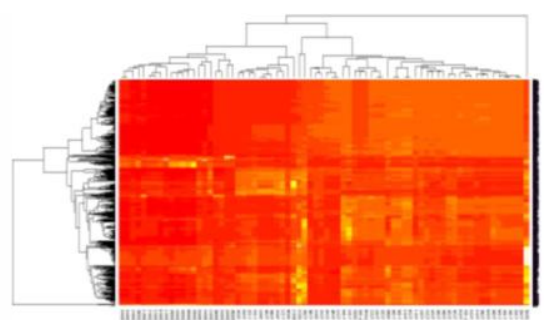

c. Average linkage

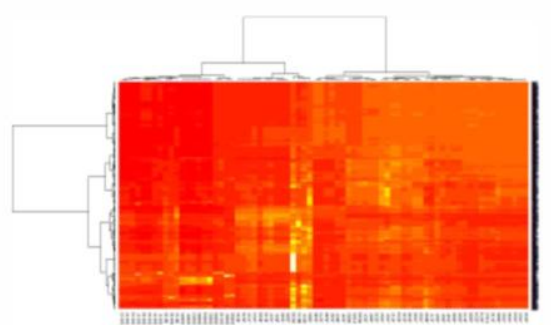

d. Ward. D. linkage

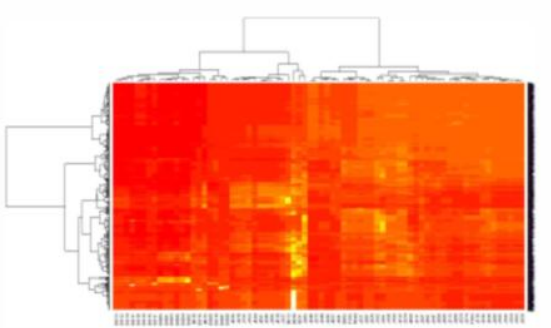

e. Ward. D2 linkage

Gambar 6. Gerombol simultan senyawa dengan protein menggunakan berbagai metode penggerombolan.

sebelah kiri cenderung bersesuaian dengan aktivitas protein di kuadran 4 sedangkan gerombol senyawa sebelah kanan lebih banyak bersesuaian dengan aktivitas protein di kuadran 2 . Berdasarkan tujuan yang ingin dicapai, maka kita lebih tertarik mengamati penggerombolan simultan yang terdapat semua senyawa sintetis di dalamnya, yaitu gerombol sebelah kiri (Gambar 7b). Terdapat total 35 senyawa yang menggerombol terdiri dari semua senyawa sintetis, 3 senyawa Bratawali, 11 senyawa Jahe dan 2 senyawa 


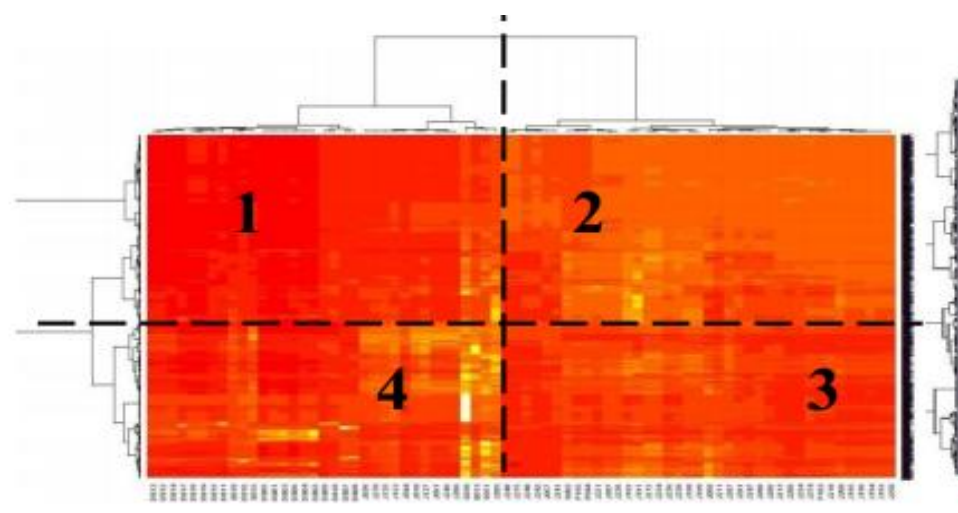

a. Gerombol simultan Ward.D

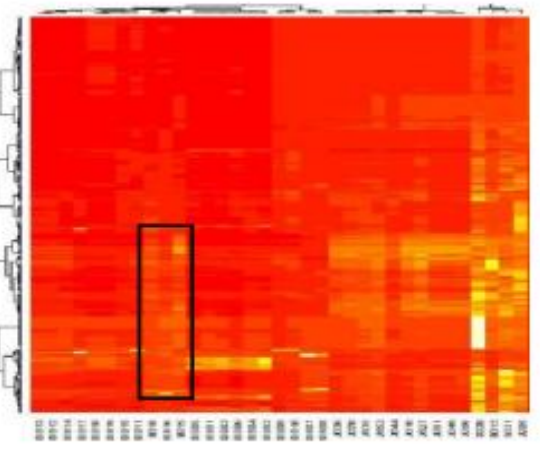

b. Gerombol kuadran $1 \& 4$

Gambar 7. Hasil gerombol simultan Ward.D

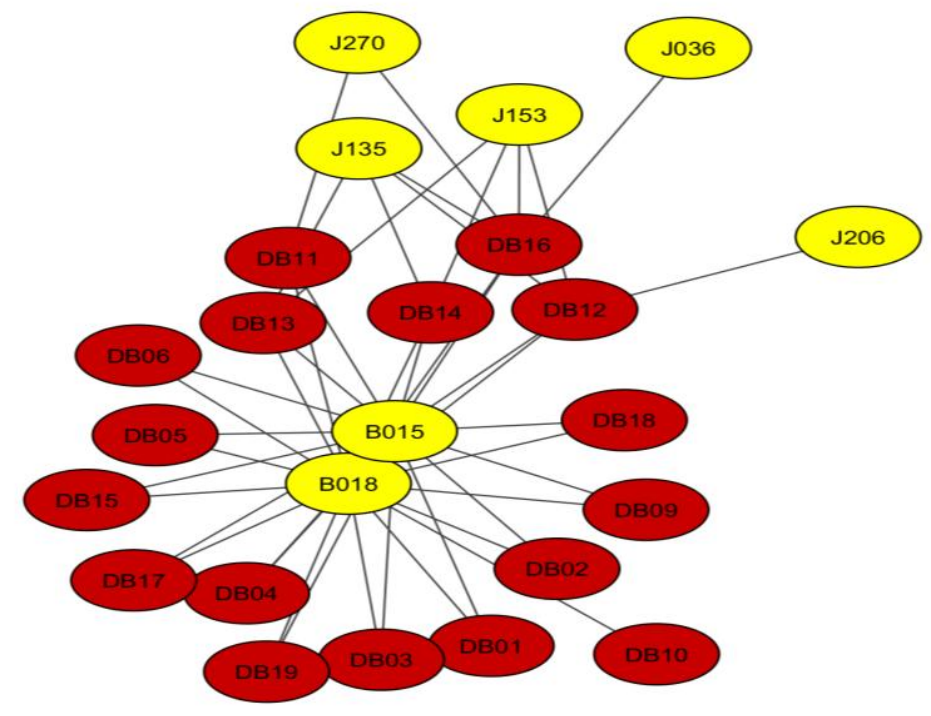

Gambar 8. Jejaring kemiripan senyawa sintetis dengan senyawa tanaman

Sembung. Senyawa Bratawali B015 dan B018 menggerombol dekat dengan senyawa sintetis, sedangkan B013 menggerombol berdekatan dengan semua senyawa Jahe dan semua senyawa Sembung. Perlu digarisbawahi bahwa aktifitas protein-protein tertentu hanya dipengaruhi oleh beberapa senyawa tertentu pula. Kotak kecil pada Gambar 7b yang menunjukkan bahwa senyawa aktif Bratawali B015 dan B018 serta senyawa aktif sintetis DB16 terlibat dalam aktifitas beberapa protein, yaitu tidak kurang dari 566 protein (dicirikan oleh warna lebih terang). Diantara protein-protein tersebut terdapat 3 protein yang merupakan protein target dari senyawa Bratawali B015 dan senyawa sintetis DB16. Ketiga protein tersebut yaitu alcohol dehydrogenase [NADP(+)] (NP_006057.1), aldose reductase (NP_001619.1), dan nuclear factor
NF-kappa-B p105 subunit isoform 1 (NP_003989.2). Akan tetapi, sehubungan aktifitas senyawa lebih dipentingkan dalam penentuan senyawa aktif ramuan jamu antidiabetes, korelasi antar senyawa akan lebih diteliti lanjut melalui jejaring kemiripan.

\section{Jejaring Kemiripan}

Gambar 8 menjelaskan bahwa terdapat 17 dari 19 senyawa obat sintetis yang memiliki kemiripan berdasarkan protein target dengan beberapa senyawa tanaman. Senyawa bratawali $\mathrm{N}$-trans-Feruloyltyramine (B015) dengan nomor CID 5280537 dan NFormylanonaine (B018) dengan nomor CID 158516 memiliki kemiripan dengan senyawa yang terkandung dalam 17 obat sintetis antidiabetes. Sedangkan jahe memiliki 5 senyawa yang mirip dengan beberapa 
senyawa sintetis yaitu [6]-Gingerol (J036) dengan nomor CID 3473 mirip dengan Tolrestat (DB16), 1,7Bis(3,4-dihydroxyphenyl)-3,5-heptanediol; (3R,5R)-form, 3,5-Diketone, 3',3"-di-Me ether (J135) dengan nomor CID 124072 dan 4-(3,4-Dihydroxyphenyl)-2-butanone; 3-Me ether (J153) dengan nomor CID 31211 mirip dengan Pioglitazone (DB12), Rosiglitazone (DB13), Repaglinide (DB14) dan Tolrestat (DB16). Selain itu, [6]Shogaol (J206) dengan nomor CID 5281794 mirip dengan Pioglitazone (DB12), serta Hexahydrocurcumin (J270) dengan nomor CID 5318039 mirip dengan senyawa sintetis Miglitol (DB11) dan Tolrestat (DB16). Berdasarkan analisis gerombol berhirarki 2 dimensi dan jejaring kemiripan, Jahe dicurigai sebagai tanaman pendukung sedangkan Bratawali sebagai tanaman utama pada ramuan jamu antidabetes. Hal ini karena Bratawali menggerombol dekat dengan senyawa sintetis dan memiliki kemiripan dengan banyak senyawa sintetis dibandingkan Jahe. Asumsi ini berdasar pada penelitian yang telah dilakukan oleh Afendi et al. (2012) yang menyatakan bahwa sebuah ramuan Jamu terdiri dari kandungan senyawa tanaman utama dan tanaman pendukung. Namun asumsi tersebut masih perlu dilakukan serangkaian uji lanjut untuk membuktikannya.

\section{Simpulan}

Terdapat setidaknya 3 kesimpulan dari hasil penelitian ini, yaitu:

- Metode analisis drugCIPHER mampu merubah kedekatan antar protein dan struktur kimia senyawa menjadi nilai numerik yang dapat dianalisis secara komputasi dan secara statistika.

- Analisis statistika penggerombolan simultan dapat digunakan sebagai pendekatan alternatif dalam penentuan senyawa aktif tanaman obat antidiabetes tipe 2 selain pendekatan farmasi melalui laboratorium.

- Jejaring kemiripan telah melengkapi hasil analisis gerombol simultan dan berhasil menunjukkan bahwa terdapat 2 dari 3 senyawa Bratawali dan 11 dari 44 senyawa Jahe yang berpotensial sebagai obat antidiabetes karena menggerombol dan berkorelasi tinggi dengan senyawa aktif antidiabetes, sebaliknya tidak demikian untuk Sembung dan Pare. Akan tetapi Sembung dan Pare mungkin berpotensi sebagai tanaman antidiabetes bila data yang digunakan lebih banyak atau dengan analisis yang lain.

\section{Saran}

Saran yang dapat disampaikan oleh peneliti berkaitan studi yang dilakukan diharapkan penelitian selanjutnya bisa mendapatkan basis data yang lebih menyeluruh sehingga menghasilkan senyawa jamu yang lengkap dan detail.

\section{Daftar Pustaka}

Afendi et al. 2010. Modelling ingredient of jamu to predict its efficacy. Forum Statistika dan Komputasi. 5(2).1-9.

Afendi F M, Darusman L K, Fukuyama M, Md. Altaf-UIAmin, Kanaya S. 2012. A Bootstrapping approach for investigating the consistency of assignment of plants to jamu efficacy by PLS-DA model. Malaysian Journal of Mathematical Sciences. 6(2):147-164.

Afendi FM, Okada T, Yamazaki M, Hirai-Morita A, Nakamura Y, Nakamura K, Ikeda S, Takahashi H , Altaf-Ul-Amin M, Darusman LK, Saito K, Kanaya S. 2012. KNApSAcK Family databases: Integrated metabolite-plant species databases for multifaceted plant research. Plant and Cell Physiology. 53(2). 1-12. doi:10.1093/pcp/pcr165

Calinski T, Harabasz J. 1974. A Dendrite Method for Cluster Analysis, Communication in Statistics. Taylor \& Francis. 3, 1-27.

Getz G, Levine E, Domany E. 2000. Coupled Two-Way Clustering Analysis of Gene Microarray Data. Proceedings of the National Academy of Sciences. Vol 97, no.22, 12079-12084.

Goel R, Harsha HC, Pandey A, et al. 2012. Human Protein Reference Database and Human Proteinpedia as resources for phosphoproteome analysis. Molecular BioSystems. 8(2). 453-463.

Govaert Gerard. 1995. Simultaneous clustering of rows and columns. Control and Cybernetics. vol.24 No.4.

Johnson RA, Wichern DW. 2002. Applied Multivariate Statistical Analysis, Fifth Edition. Englewood Cliffs, New Jersey: Prentice Hall.

Klekota Justin, Roth Frederick P. 2008. Chemical Substructures that Enrich for Biological Activity. Bioinformatics, 24:2518-2525.

Li Huiying et al. 2014. A Network Pharmacology Approach to Determne Active Compounds and Action Mechanisms of Ge-Gen-Qin-Lian Decoction for Treatment of Type 2 Diabetes. 
Hindawi Publisging doi:10.1155/2014/495840.

Mudunuri U, Che A, Yi M, Stephens RM. 2009. bioDBnet: the biological database network. Bioinformatics. 25(4). 555556.doi:10.1093/bioinformatics/btn654.

Nurishmaya MRN. 2014. Pendekatan Bioinformatika Formulasi Jamu Baru Berkhasiat Antidiabetes dengan Ikan Zebra (danio rerio) Sebagai Hewan Model [Skripsi]. Bogor(ID): Institut Pertanian Bogor.

Parsons $A B$, Brost RL, Ding $H$, Li Z, Zhang C, Sheikh B, Brown GW, Kane PM, Hughe TR, Boone B. 2004. Integration of chemical-genetic and genetic interaction data links bioactive compounds to cellular target pathways. Nature Biotechnology. $22,62-69$.
Sharma A, Pranit S Lal. 2011. Tanimoto based similarity measure for intrusion detection system. Journal of Information Security. 2, 195-201.

Wang Y, Xiao J, Suzek TO, Zhang J, Wang J, Bryant SH. 2009. PubChem: a public information system for analyzing bioactivities of small molecules. Nucleic Acids Res. 2(8).1-11. doi:10.1093/nar/gkp456.

Wishart DS, Knox C, Guo AC, Cheng D, Shrivastava S, Tzur D, Gautam B, Hassanali M. 2008. DrugBank: a knowledgebase for drugs, drug actions and drug targets. Nucleic Acids Res. 2008 Jan;36(Database issue):D901-6.

Zhao S, Li S. 2010. Network-based relating pharmacological and genomic spaces for drug target identification. PLOS ONE. 5(7): e11764. doi:10.1371/journal.pone.0011764 